\title{
Addressing the challenges of teaching legal ethics to take account of the widening participation agenda
}

\begin{abstract}
This paper will seek to address the challenges of teaching legal ethics to undergraduate law students, both generally and in my own institutional context. Ethical conduct has long been held to be a central feature of professionalism and, traditionally, codes of ethics constituted one of the hallmarks and defining characteristics of the professions. The legal profession is no exception to this, however, it has not always been recognised that university law schools have an important role to play in preparing law students for the ethical challenges of legal practice. More recently this indifference has given way to an acceptance of the importance of this area of learning. Rather than being whether to teach legal ethics to law students, therefore, the two fundamental questions for educators are, firstly, what do students need to learn from the teaching of legal ethics and, secondly, how this is to be achieved. This study also aims to consider the specific challenges of teaching legal ethics to law students from widening participation backgrounds. These issues are particularly important in my own professional context as programme leader for an undergraduate qualifying law degree at an institution with a high population of widening participation students.
\end{abstract}

\section{Introduction}

This paper will seek to address the challenges of teaching legal ethics to undergraduate law students, both generally and in my own institutional context. Ethical conduct has long been held to be a central feature of professionalism and, traditionally, codes of ethics constituted one of the hallmarks and defining characteristics of the professions. ${ }^{1}$ The legal profession is no exception to this, however, it has not always been recognised that university law schools have an important role to play in preparing law students for the ethical challenges of legal practice. More recently this indifference has given way to an acceptance of the importance of this area of learning, in particular in light of the reiteration of the role values and ethics should play in legal education in the Report of the Legal Education and Training Review (LETR). ${ }^{2}$ Rather than being whether to teach legal ethics to law students, therefore, the two fundamental questions for educators are, firstly, what do students need to learn from the teaching of legal ethics and, secondly, how this is to be achieved. ${ }^{3}$ These issues are particularly important in my own professional context as programme leader for an undergraduate qualifying law degree, specifically the Bachelor of Laws (LLB), which is the academic stage of training for those intending to practice as solicitors or

\footnotetext{
1 I. Lunt, "Ethical Issues in Professional Life" in B. Cunningham (ed), Exploring Professionalism (Institute of Education, University of London, 2008).

2 J. Webb, A. Sherr, J. Ching and P. Maharg (LETR), Setting Standards: The Future of Legal Services Education and Training Regulation in England and Wales (2013) http://www.letr.org.uk/the-report/ (accessed 18 March 2018).

${ }^{3}$ M. Robertson, L. Corbin, K. Tranter and F. Bartlett (eds) The Ethics Project in Legal Education (Abingdon, Routledge, 2011).
} 
barristers in England and Wales. This study also aims to consider the specific challenges of teaching legal ethics to law students from widening participation backgrounds. This is especially relevant to me since the institution where I teach, in common with many others and as required by the Higher Education Funding Council for England (HEFCE), operates a policy of widening access. Hence, many of the students whom I teach are the first generation of their family to enter higher education, many are older mature students and many come from diverse social and ethnic backgrounds.

\section{The importance of teaching legal ethics}

For ease of reference the term '(university) law school' will be used throughout interchangeably with '(undergraduate) legal education'. Academic resistance to teaching ethics in legal education has traditionally focused on arguments that it is more appropriate to teach ethics subsequent to the degree, as part of vocational training (e.g. the Australian Law Admissions Consultative Committee have recommended that Ethics and Professional Conduct be situated in practical legal training following the degree.) ${ }^{4}$ However, vocational ethics teaching often does little more than introduce students to the formal conduct rules found in the professional codes i.e. the Code of Conduct for solicitors ${ }^{5}$ and for barristers, ${ }^{6}$ which is too little, too late. ${ }^{7}$ Several reports published in recent years have indicated a broad interest in including some aspect of ethics in pre-practice legal education across the common law world (i.e. those jurisdictions, like England and Wales, whose body of law is derived from judicial decisions rather than solely from legislative codes). The Lord Chancellor's Advisory Committee on Legal Education and Conduct (ACLEC) in England asserted that a law curriculum should emphasise legal values of "justice, fairness and high ethical standards." ${ }^{8}$ The Australian Law Reform Commission (ALRC) noted that a healthy professional culture is one that values lifelong learning and takes ethical concerns seriously. ${ }^{9}$ In the USA, the influential Carnegie Report claimed that law schools should "initiate novice practitioners to think, to perform, and to conduct themselves (that is, to act morally and ethically) like professionals."10

\footnotetext{
${ }^{4}$ Law Admissions Consultative Committee, "Review of Academic Requirements for Admission to the Legal Profession", http://www1.lawcouncil.asn.au/LACC/images/

pdfs/01.12.14_Review_of_Academic_Requirements_for_Admission.pdf (accessed 2 September 2018).

5 Solicitors Regulation Authority (SRA), SRA Code of Conduct (2011), https://www.sra.org.uk/solicitors/handbook/code/content.page (accessed 18 March 2018).

${ }^{6}$ Bar Standards Board (BSB), BSB Code of Conduct (2014), https://www.barstandardsboard.org.uk/media/1553795/bsb handbook jan 2014.pdf (accessed 18 March 2018).

7 D. Nicolson, “Education, Education, Education': Legal, Moral and Clinical” (2008) 42(2) The Law Teacher 145-172.

8 Lord Chancellor's Advisory Committee on Legal Education and Conduct (ACLEC), First Report on Legal Education and Training (London, ACLEC, 1996) para 2.4.

${ }^{9}$ Australian Law Reform Commission (ALRC), Managing Justice: A Review of the Federal Civil Justice System (Report No. 89, 1999) http://www.alrc.gov.au/report-89, Ch.2, para 2.3 (accessed 18 March 2018).

10 W. Sullivan, A. Colby, J. Welch Wegner, L. Bond and L. Shulman, Educating Lawyers:

Preparation for the Profession of Law (2007)
} 
In 2014 the Canadian Bar Association also acknowledged the place of ethics in the future of lawyers in Canada, equating the importance of ethics and values with economics and values. ${ }^{11}$

The importance of ethics and values within legal education and training was stressed most recently in England and Wales by the LETR, which recommended in 2013 that legal education should include appropriate learning outcomes in respect of professional ethics. Specifically, under Recommendation 7 of the LETR:

"the learning outcomes at initial stages of LSET [legal services education and training] should include reference... to an understanding of the relationship between morality and law, the values underpinning the legal system, and the role of lawyers in relation to those values."12

The recommendations of the LETR have now been incorporated into the Solicitors Qualifying Examination (SQE), which it is proposed will be introduced by 2020-21 by the Solicitors Regulation Authority (SRA), which all prospective solicitors will need to pass in order to qualify. There are two stages to the SQE: the first will consist of online testing of legal knowledge, including the type of topics currently covered on a qualifying law degree; the second will focus on practical legal skills, such as writing, research, interviewing and advocacy. At both stages candidates will be expected to identify relevant legal principles and apply them to client-based and ethical problems encountered in practice. ${ }^{13}$ This is done through assessments that integrate substantive and procedural law and also test ethical judgment using computer-based testing at stage one and legal research, written advice and drafting assessments at stage two. These question formats usually include a scenario where candidates have to apply their knowledge to the given context. In terms of what is being tested, the SQE draft assessment specification sets out the assessment objectives in relation to ethics, professionalism and judgment as follows:

"A1 Act honestly and with integrity, in accordance with legal and regulatory requirements and the SRA Handbook and Code of Conduct. A4 Draw on a sufficient detailed knowledge and understanding of their field(s) of work and role in order to practise effectively.

A5 Apply understanding, critical thinking and analysis to solve problems."14

In addition to passing the SQE, it has also been necessary since 2011 for all new solicitors to meet the SRA's character and suitability requirements,

http://archive.carnegiefoundation.org/pdfs/elibrary/elibrary pdf 632.pdf, p.22 (accessed 18 March 2018).

11 Canadian Bar Association, Futures: Transforming the Delivery of Legal Services in Canada (2014) http://www.cbafutures.org/CBA/media/mediafiles/PDF/Reports/Futures-Finaleng.pdf?ext=.pdf, p.3 (accessed 18 March 2018).

12 Webb et al., supra n.2, para 7.89 .

${ }^{13}$ Solicitors' Regulation Authority (SRA), SQE draft assessment specification (2017) https://www.sra.org.uk/documents/SRA/news/sqe-draft-assessment-specification.pdf (accessed 2 September 2018).

14 Ibid, p.11. 
assessed by a questionnaire obliging them to disclose anything relevant to these requirements e.g. criminal convictions.

While the importance of ethics as an area of knowledge is therefore commonly recognised by the relevant legal professional bodies in Australia, the USA and Canada, as well as in England and Wales, what is not universally agreed upon is where ethics as an area of learning should be situated..$^{15}$ There are no recommendations in the LETR, for example, as to content or delivery of ethical education and training. Instead the LETR leaves sufficient flexibility for providers of LSET to design learning outcomes and assessments, as well as the restructuring - if required - of their law programmes to implement its ethical recommendations. The question then arises of how to teach professional ethics, as it is left to individual academic institutions to decide what ethics is to mean to them and their students. ${ }^{16}$

\section{What do students need to learn from the teaching of legal ethics?}

Legal ethics includes both professional ethics i.e. as set down in formal codes and values i.e. those values that specifically underpin the rule of law: these two areas link up with a concern for professionalism. ${ }^{17}$ In relation to the teaching of legal ethics the law school focus has traditionally been narrow, with a focus upon "law as rules" 18 that encourages students to consider moral conduct as rule-following. ${ }^{19}$ This narrow view is of professionalism as technical competence and adherence to the written rules of the profession only. The drawback of this view is that it implies that, when faced with an ethical dilemma, solicitors for example will tend to look to the Solicitors' Code of Conduct 2011 (the Code) for an answer rather than consulting their own moral values. Whilst solicitors comply with the Code, they do not do so blindly and will use their own moral values to interpret Code requirements. This might produce different results depending on those values e.g. leading one solicitor to withdraw while another would not. The narrow view as referred to above also now appears expressly incompatible with the rules themselves. In 200910 the change in the governance of the solicitors' profession to an outcomesfocused approach to regulation required a significant shift in practitioners' thinking. Rather than seeking to set out detailed guidance on specific issues, the Code instead emphasises general points of principle, which it then leaves solicitors to apply in the circumstances that they face.

The ten key principles of the Code introduced in 2011 include the duty to uphold the rule of law and the proper administration of justice, act with integrity, act in the best interests of each client and behave in a way that maintains public trust in the legal profession (the code of conduct for barristers has since 2014 been based on similar principles). These key

\footnotetext{
${ }^{15} \mathrm{M}$. Evers and L. Townsley, "The Importance of Ethics in the Law Curriculum: Essential or Incidental?" (2017) 51(1) The Law Teacher 17-39.

${ }^{16} \mathrm{C}$. Sandford-Couch and J. Bainbridge, "Educating towards Ethical Lawyers: A Progress Report" (2015) 49(3) The Law Teacher 336-352.

17 G. Ferris, "Values Ethics and Legal Ethics: The QLD and LETR Recommendations 6, 7, 10, and 11" (2014) 48(1) The Law Teacher 20-32.

${ }^{18} \mathrm{P}$. Baron and L. Corbin, "Thinking like a Lawyer/acting like a Professional: Communities of Practice as a Means of Challenging Orthodox Legal Education" (2012) 46(2) The Law Teacher 100, p.104.

19 lbid.
} 
principles (or 'mandatory outcomes') form an overarching framework within which the more detailed and context-specific rules (or 'non-mandatory indicative behaviours') in the rest of the Code can be understood, ${ }^{20}$ thus illuminating the nature of those obligations and helping solicitors to comply. The intention behind the new focus on principles - rather than specific professional conduct rules - seemed to have been to encourage a more selfreflective, autonomous approach, "which places a greater emphasis on the ethical values of the individual legal practitioner." 21 This hearkens back to a broader and more traditional view of professionalism that is characterised by a number of attributes going far beyond mere technical competence and opens new spaces of negotiation for debates around liberal education and vocationalism.

In the context of ethics, the vocational approach of simply teaching ethical codes may help students to gain a conceptual vocabulary but is not enough to develop their ethical awareness. Maintaining the law degree as a general or liberal qualification is also desirable given that an important element of the signature of the systems of university law schools that exist in the United Kingdom is the fact that, in the main, they pursue a liberal education. ${ }^{22} \mathrm{~A}$ liberal legal education is regarded as one which does not focus on education for a particular purpose other than education itself, ${ }^{23}$ the main aim of which is preparing law students to develop into better citizens rather than simply good lawyers. ${ }^{24}$ This is a mission which exposure to the general ethical theory behind legal ethics, with its focus on values, aims to encourage. Attention to lawyers' ethics therefore seems essential to a liberal legal education; 25 indeed it has been stated: "a liberal legal education must address values in both the substantive curriculum and in its approach to pedagogy." 26 Teaching professional ethics could mean a tacit acceptance of the vocational element of the law degree. But teaching professional ethics in a manner that makes students aware of the limitations of the professional conduct rules allows students to understand legal ethics, while also acknowledging the importance of law as a liberal arts degree. In this sense the very concept of a division between an academic and vocational legal education is artificial, with a liberal legal education being conceived of as including the preparation of lawyers for practice as well as developing knowledge and skills for their own sake. Duncan shares this view that a professional legal education is one version of a liberal or academic education. ${ }^{27}$

This conception is particularly important given that many law graduates choose careers outside the legal profession - only around $20 \%$ of law

\footnotetext{
20 SRA, supra n.5, Introduction.

${ }^{21}$ Sandford-Couch and Bainbridge, supra n.16, p.337.

22 A. Bradney, "Elite Values in Twenty- first Century, United Kingdom Law Schools" (2008)

42(3) The Law Teacher 291, p.291.

$23 \mathrm{~J}$. Turner, A. Bone and J. Ashton, "Reasons Why Law Students Should Have Access to Learning Law through a Skills-Based Approach" (2016) 52(1) The Law Teacher 1, p.4.

${ }^{24}$ R. Burridge and J. Webb, "The Values of Common Law Legal Education: Rethinking Rules,

Responsibilities, Relationships and Roles in the Law School" (2007) 10(1) Legal Ethics 72-97.

${ }^{25}$ Nicolson, supra n.7.

${ }^{26}$ F. Cownie, "Alternative Values in Legal Education" (2003) 6(2) Legal Ethics 159, p.160.

27 N. J. Duncan "A future for legal education: Personal and professional development and ethics" (2015) 24 Nottingham Law Journal 67, p. 68.
} 
graduates become solicitors for example. ${ }^{28}$ As a consequence, legal education providers must ensure that law graduates are equipped with the knowledge and skills to enable them not only to go on to become solicitors and barristers, but also to enter and operate effectively within other fields, while being able to reflect on their practice in light of ethical values of what it means to be and act as a professional. ${ }^{29}$ Teaching a broader conception of ethics that encompasses values rather than a narrow focus on legal ethics is important for the development of the professional identity of law students. ${ }^{30}$ Professionalism in the narrow sense implies regulation of law practitioners by the professional bodies but professionalism can also be understood in the wide sense, which does not require regulation by the professional bodies and focuses instead on skills, values and attitudes that any professional should possess $^{31}$ as well as, importantly, a sense of public obligation. ${ }^{32}$ This wider notion of professionalism places more stress on skills, values and attitudes that guide one's behaviour when providing legal advice, instead of focusing on knowledge acquisition and regulation by professional bodies. In this context the focus of legal education should be on developing the common standard of professional skills, values and attitudes that are universal and transferable: accepted not only by the legal profession but also by others. These professional values could include e.g. handling cases professionally (i.e. with diligence, punctuality, courtesy, honesty and at a fair cost), managing law practice effectively and efficiently, engaging in professional self-development, nurturing quality of life and supporting the aims of the legal profession (i.e. providing access to justice, promoting fairness and encouraging diversity). ${ }^{33}$

Ferris refers to the Four Component Model developed by Rest as one model of the causative factors that underlie ethical action that illustrates why an outcomes focus can be problematic in ethical education. The four components that Rest argues need to be present for effective ethical action are sensitivity, judgment, motivation and character. Since the nature of the values adopted (the second and third of Rest's components) can be subject to legitimate and radical difference of opinion, to "try and assess within this sphere... becomes a politically divisive conformity test." 34 Teaching values ethics in legal education, depending on what you are seeking to assess, may therefore be fraught with difficulties. Having said this, the literature is clear that legal education needs to change its narrow focus of training students to think like lawyers to educating them to act like professionals and to assist students to construct their professional identity. The literature is also clear that what this entails is not only teaching skills to students, but also a sense of professional values and public obligation. What is perhaps less clear, or at least what appears to be more open to interpretation, is exactly how university

\footnotetext{
${ }^{28}$ The Law Society, Entry Trends (2018) https://www.lawsociety.org.uk/Lawcareers/Becoming-a-solicitor/Entry-trends (accessed 18 March 2018).

${ }^{29} \mathrm{E}$. Dagilyte and P. Coe, "Professionalism in higher education: important not only for lawyers" (2014) 48(1) The Law Teacher 33, p.41.

${ }^{30}$ M. Rowe, M. Murray and F. Westwood, "Professionalism in Pre-Practice Legal Education: An Insight into the Universal Nature of Professionalism and the Development of Professional Identity" (2012) 46(2) The Law Teacher 120-131.

${ }^{31}$ Dagilyte and Coe, supra n.29, p.37.

32 Baron and Corbin, supra n.18.

${ }^{33}$ Rowe, Murray and Westwood, supra n. 30.

${ }^{34}$ Ferris, supra n. 17.
} 
law schools are to achieve this training in professionalism, especially in the context of the many challenges facing higher education today.

\section{What are the challenges of teaching legal ethics in the context of widening participation?}

A key message of the LETR is a desire to increase diversity in the legal profession, with ethical education and training being seen as a known and potentially effective solution to a lot of problems identified in this and other key messages. ${ }^{35}$ It has also been noted that social mobility in legal education provides critical benefits not just for the affected individuals but also for broader society e.g. having a more socially representative legal profession. ${ }^{36}$ Since part of the drive to introduce ethics teaching in legal education stems from a desire on the part of the professional bodies to encourage diversity, it seems particularly important to consider the challenges of teaching legal ethics in the context of widening participation. This is a generic term used to signify a range of national and local initiatives designed to recruit students from non-traditional social, economic and ethnic backgrounds into higher education. ${ }^{37}$ In terms of policy, widening participation has its origins in the Dearing Report, ${ }^{38}$ which recommended that the government should introduce policies that encourage and support students from disadvantaged backgrounds, whose social demography, amongst other things, had traditionally denied them the opportunity to attend higher education. It is now a requirement of HEFCE that universities have a widening participation strategy. ${ }^{39}$ Legal education is just one aspect of widening participation, with the result that in the last 20 years or so an increasing number of students now attending university law schools are the first to do so from their families or are formerly under-represented learners (e.g. working class, ethnic minority or disabled students). ${ }^{40}$

To compensate for the lack of participation in higher education, it has been proposed that university culture must be demystified for prospective first-generation university entrants. ${ }^{41}$ Many widening participation students may not have had a professional role model in their lives: Wilkins and Burke refer to the difficulties encountered by young people of a working-class background who typically lack the educational and aspirational opportunities

\footnotetext{
${ }^{35}$ lbid.

${ }^{36} \mathrm{~L}$. Ferguson, "Complicating The 'holy grail,' Simplifying the Search: A Critique of the Conventional Problematisation of Social Immobility in Elite Legal Education and the Profession" (2017) 51(4) The Law Teacher 377-400.

${ }^{37}$ P. Redmond, "Outcasts on the inside: Graduates, Employability and Widening Participation" (2006) 12(2) Tertiary Education and Management 119, p.119.

${ }^{38}$ National Committee of Inquiry into Higher Education (Dearing Report), Higher Education in the Learning Society (1997)

http://www.educationengland.org.uk/documents/dearing1997/dearing1997.html (accessed 20 March 2018).

${ }^{39} \mathrm{~T}$. Bowers-Brown, "Widening participation in higher education amongst students from disadvantaged socio-economic groups" (2006) 12(1) Tertiary Education and Management 5974.

${ }^{40}$ B. Waters, "Widening Participation in Higher Education: The Legacy for Legal Education" (2013) 47(2) The Law Teacher 261-269.

${ }^{41}$ Bowers-Brown, supra n. 39.
} 
made available by middle-class parents. ${ }^{42}$ It is therefore important that academics lead students by example by "consistently demonstrating what it means to be professional." ${ }^{43}$ This potential for law schools to influence character development is emphasised by the fact that incoming law students may only have developed a moral character in relation to the sort of moral issues that arise in personal or family life, rather than as part of the development of their professional identity in response to professional moral problems. In other words, "while they might have a developed personal moral character, they have yet to develop a professional moral character" 44 and, as law teachers generally are the first to introduce them to the legal world, they have a unique opportunity to influence this process.

Student (dis)engagement is another issue in the teaching of legal ethics to widening participation students that has been identified. ${ }^{45}$ Research by Rowe, Murray and Westwood has shown that, based on their backgrounds, not all students placed the same importance on professional values such as diligence, respect for peers, clear and timely communication and time management. ${ }^{46}$ In developing its legal ethics curriculum and in response to student feedback, an Australian university aimed specifically to develop students as ethical and reflective practitioners who also have a strong sense of personal integrity. ${ }^{47}$ Students also need to be made to understand that meeting deadlines, treating other students and staff with respect and submitting quality work are marks of professionalism and the expectations of legal practice; they are not "simply demands universities make for their own sake." 48 A limited range of suitable extra-curricular activities has also been proposed as one explanation for lack of engagement in university life on the part of widening participation students. ${ }^{49}$ Ferguson also considers that in order to be able to make the most of available opportunities, disadvantaged students must participate fully in the non-academic aspects of university life, and should be encouraged to do so. ${ }^{50}$ An awareness of ethical principles can be made available through student engagement in extracurricular activities, such as law clinics (considered further in the next section) and other legal projects e.g. mooting and debating.

Also of particular relevance to law students from widening participation backgrounds is the increasing call for resilience training for lawyers and law students ${ }^{51}$ in response to a gap in legal education. There is a general acceptance by researchers, academics and the legal profession that law students would benefit from greater resilience and stress management strategies. The first year of law study has been identified as "a significant time

\footnotetext{
42 A. Wilkins and P. J. Burke, "Widening Participation in Higher Education: The Role of Professional and Social Class Identities and Commitments" (2015) 36(3) British Journal of Sociology of Education 434, p.445.

43 Dagilyte and Coe, supra n.29, p.47.

44 Nicolson, supra n.7, p.160.

45 M. Travis, "Teaching professional ethics through popular culture" (2016) 50(2) The Law Teacher 147-159.

46 Rowe, Murray and Westwood, supra n.30, p.125.

47 Evers and Townsley, supra n.15, p.20.

48 Baron and Corbin, supra n.18, p.111.

${ }^{49}$ Redmond, supra n.37.

${ }^{50}$ Ferguson, supra n.36.

${ }^{51}$ Evers and Townsley, supra n.15, p.32.
} 
for students to develop psychological distress," ${ }^{2}$ such as anxiety and depression, largely attributed to workload and the competitive environment within law schools. This is especially the case for widening participation students who may have less experience in a formal educational setting and may be unfamiliar with the institutions, goals and processes of legal education. Widening participation students often have qualifications other than the traditional GCSEs and 'A'-Levels on entry and may also be mature students who have not been in a classroom for many years. Since such students are often the ones who will need the most support when they first start university, there is a need to facilitate their awareness and management of their professional identity if they are to become legal professionals.

One of the common problems of professional education and training in the context of widening participation is the "hidden curriculum that is embodied in the way (law) schools are organized, classes are conducted and values transmitted in informal ways." ${ }^{3}$ This is knowledge that the newcomer cannot learn simply by demonstration or instruction: "It includes learning the language and unspoken conventions of the community." ${ }^{4}$ Again, this has particular relevance to widening participation students. Students from such backgrounds are often likely to need as much assistance in order to gain the necessary cultural capital i.e. those attributes and skills most highly valued by potential employers ${ }^{55}$ to succeed in their careers beyond university, as they will in their development as learners. But this hidden curriculum, also called soft knowledge, is not realised simply by teaching ethics subjects: it is only realisable when ethical principles have been fully integrated into the student's professional identity. ${ }^{56}$ The unarticulated value assumptions contained in the hidden curriculum "are communicated to students by example, teaching methods, curriculum choices... and by student culture and contacts with the legal profession." 57 These methods and choices will be considered further in the next section.

\section{How do we go about teaching legal ethics to law students from widening participation backgrounds?}

Moving on from the question about the nature and quality of learning that is regarded as important, it is helpful to consider the kinds of approaches and strategies that might be used to address the challenges of teaching legal ethics. A wide variety of approaches is suggested in the literature. This shows the need for a tailored approach, adapted to each specific institution and its students i.e. widening participation in the context of my own university. The University of East London (UEL) has a law school with a diverse student body: ${ }^{58}$ a majority of non-white students in the region of 80:20; the age profile of those enrolling in $2016 / 17$ was 37 students over the age of 21 out of a

\footnotetext{
52 Ibid, p.33.

53 Rowe, Murray and Westwood, supra n.30, p.122.

${ }^{54}$ Baron and Corbin, supra n.18, p.113.

55 Higher Education Academy (HEA), Inclusive curriculum design in higher education - Law

(2011) https://www.heacademy.ac.uk/knowledge-hub/inclusive-curriculum-design-higher-

education, p.4 (accessed 21 March 2018).

${ }^{56}$ Baron and Corbin, supra n.18, p.113.

57 Nicolson, supra n.7, p.148.

58 HEFCE, Unistats (2017) http://unistats.direct.gov.uk/ (accessed 21 March 2018).
} 
cohort of 76; and 21 students out of this cohort had qualifications on entry other than 'A'-Level or equivalent (they joined on successful completion of an access course for which no formal qualifications were required). At UEL legal ethics is currently taught and assessed in the law curriculum as a discrete topic in the first year compulsory module Legal System and Legal Reasoning. In this module students are presented with ethical dilemmas in a practical context (e.g. 'You discover that your friend sells cannabis to other students at her college - would you report her to the police?'), preceded by a discussion of what values are expected of a lawyer. Students almost always simply say yes or no in response to the dilemmas and they are then asked to reflect further on their choices by trying to identify the values underpinning them by reference to the values identified in the earlier discussion. The purpose of these activities, therefore, is not to arrive at any one 'right' resolution to each ethical dilemma, but instead to identify the possible moral, ethical, legal issues that are raised in each case and reflect on them in light of the values expected of a lawyer. Students do not come across ethics again as a topic in any core modules, although Corporate Ethics, Governance and Sustainability, a final year optional module with a greater focus on legal ethics, is also due to be introduced in the 2019-20 academic year. It should be noted that the undergraduate qualifying law degree at UEL was last validated in 2013-14, before the dissemination of the LETR and finalisation of the SQE. The revalidation of the LLB programme in 2018-19 therefore offers an opportunity to reshape the law curriculum to better address legal ethics by reference to the suggestions made in the relevant literature as well as feedback from students and employers.

There is a consensus in the literature that legal ethics can be taught in three main ways: discretely, pervasively and in a clinical setting. Of these three, it is the first approach that is currently used at UEL, with discrete modules on the law programme focusing exclusively on ethical issues that draw on areas of substantive law with which students are already familiar. The drawback of discrete teaching is that it can encourage the isolation of ethical questions from other areas of the syllabus. ${ }^{59}$ Johnstone and others argue that legal ethics should be taught as a pervasive set of values that underpin the practice of law, rather than by reference only to practical ethical problem solving. ${ }^{6061}$ The pervasive approach considers ethical questions obliquely as they arise in the context of every module. There is, however, a drawback to a pervasive in comparison to a discrete approach, in that tackling ethical questions only as they arise incidentally risks giving students the message that ethics are only of marginal concern. This can lead students to conclude that subjects taught pervasively are unimportant. ${ }^{62}$ Pervasive teaching is also dependent upon the enthusiasm of individual tutors for its implementation and might require too great a commitment from too many academic staff. ${ }^{63}$ It is

\footnotetext{
59 J. Chapman, "Why Teach Legal Ethics to Undergraduates?" (2002) 5(1) Legal Ethics 6889.

${ }^{60}$ M. Keyes and R. Johnstone, "Changing Legal Education: Rhetoric, Reality, and Prospects for the Future" (2004) 26 Sydney Law Review 537, p.550.

61 R. Johnstone, "Whole-of-Curriculum Design in Law" in S. Kift, J. Cowley, M. Sanson and P. Watson (eds) Excellence and Innovation in Legal Education (Chatswood, LexisNexis, 2011) p.2-3.

62 Chapman, supra n.59.

63 Sandford-Couch and Bainbridge, supra n.16.
} 
preferred, however, because, when legal ethics pervades the curriculum, opportunities to explore ethical issues and to practice making ethical judgments are frequent and arise in different contexts. ${ }^{64}$

The danger of relying solely upon the pervasive approach is that students encountering ethics would only cover a fraction of the material covered in a discrete ethics module. It is for this reason that Ferris argues that where ethics is taught pervasively throughout the law degree it should be supported by introductory keystone and concluding capstone modules. ${ }^{65}$ Such an approach could be utilised at UEL by adapting the aforementioned Legal System module as a keystone and introducing a final year project/dissertation as a capstone module. If this pervasive approach were introduced at UEL, it would also be necessary for the nature and quality of student learning in legal ethics to be expressed in terms of curriculum-wide ethics learning outcomes. The setting of these objectives is not a straightforward exercise, in the opinion of Robertson, unless they are stated very briefly e.g. in terms such as "graduates will be ethically competent."66

The pervasive approach has been utilised effectively at other universities with high widening participation populations. Sandford-Couch and Bainbridge referred to the approach taken at Northumbria University of providing ethics learning opportunities throughout the curriculum in each year of the law degree as being a mixed success. ${ }^{67}$ Whilst student feedback was generally positive, there were practical issues, such as staff reluctance to change their teaching. At UEL more modules could include exercises involving practical ethical dilemmas as part of this pervasive approach. For example, an ethics scenario in Family Law could cover what a divorce lawyer should do where their firm has previously acted for both a husband and wife. Similarly, in Criminal Law the problem could be what a defence lawyer acting for two clients jointly charged with burglary should do if one of them wants to change their plea. Almost every law module at UEL could adopt comparable subject-specific activities into their syllabus, although as at Northumbria much would depend on the willingness of staff as much as students to engage. Student feedback sought for revalidation purposes at UEL favours modules that "help at developing the practical, problem-solving and reflective skills for the legal professional sector." 68 This suggests that UEL students, at least, are likely to welcome such an approach. Also of importance, linking back to the point made above about specifying learning outcomes, is making it clear what is to be achieved from such exercises. This will be considered further in the next section.

The clinical approach "provides real or simulated opportunities for students to provide legal advice, learning through application, practice and reflection."69 Student law clinics and clinical legal education (CLE) modules, which simulate legal practice with real clients in order to encourage the

\footnotetext{
${ }^{64}$ Evers and Townsley, supra n.15, p.21.

65 Ferris, supra n. 17.

66 M. Robertson, "Providing Ethics Learning Opportunities throughout the Legal Curriculum"

(2009) 12(1) Legal Ethics 59, p.65.

67 Sandford-Couch and Bainbridge, supra n.16.

${ }^{68}$ University of East London (UEL) Revalidation Document - LLB (Hons) Law (2018)

appendix 6.

69 Chapman, supra n.59, p.83.
} 
development of professional identity in pre-practice legal education, potentially play a key role in encouraging students into a deeper appreciation of ethical practice. ${ }^{70}$ In these work-integrated contexts, students working under supervision benefit from contact with live clients and real cases, which lead them to experience the actuality of ethical decision-making. This sort of experiential learning, whereby students learn through direct participation in areas such as client interviewing and negotiation, rather than through more passive traditional teaching methods, can simultaneously create opportunities for learners to have increased exposure to the operation of law in practice as well as to "critically reflect on the meaning and purpose of law, research and ethical considerations." ${ }^{\prime 1}$ Curran et al. provide useful guidance as to how CLE can be used to develop ethical understanding with the experience of the law clinic at La Trobe University in Australia. ${ }^{72}$ Recommendations in this regard include the need for supervision expertise on the part of programme directors, clear objectives related to ethical practice, learning resources that include reference to different models of lawyering, regular opportunities for students to discuss ethical issues in both group and one on one interactions, clear limits on file/project numbers and students keeping reflective journals.

An important aspect of CLE is self-reflection and understanding the development of professional skills through such reflection - this is one of the core benefits of CLE that enables students to 'learn by doing'. Critical evaluation of self and others in class and self-reflective journals may enhance understanding and develop the lifelong learning skills of the reflective practitioner. ${ }^{73}$ Importantly, given the preceding discussion, experiential learning can therefore meet the needs of both those advocating a vocational approach to teaching legal ethics and those pursuing a liberal legal education. Another benefit of the clinical approach is its potential to open law schools to communities of practice, considered further below, by making known the shared norms of the legal profession and to thereby engage students with the aforementioned hidden curriculum in order to provide them with a professional identity and a sense of belonging. ${ }^{74}$ As a highly relevant extra-curricular activity, law clinics also have the potential to tackle the issue of disengagement among widening participation students discussed above. UEL is well placed to utilise this clinical approach, as the law school has a voluntary student law clinic and offers an optional CLE module. The clinical approach is unlikely to reach all law students at UEL, however, as a limited number of volunteers participate in UEL's law clinic (roughly $10 \%$ of the overall student body) and the CLE module is reserved for final year students. The narrow focus of the UEL law clinic is another issue that has been raised in student feedback sought for revalidation purposes: "not everybody is interested in the few areas of law that the Law Clinic specialises in." 75 Although CLE can be expensive and resource intensive, Nicolson has

\footnotetext{
70 Robertson, supra n.66, p.73.

71 Turner, Bone and Ashton, supra n.23, p.4.

72 L. Curran, J. Dickson and M. Noone, "Pushing the boundaries or preserving the status quo? Designing clinical programs to teach law students a deep understanding of ethical practice" 8 Journal of Clinical Legal Education 104-122.

73 Nicolson, supra n.7, p.164.

74 Baron and Corbin, supra n.18, p.118.

75 UEL, supra n.68.
} 
suggested ways of making the clinical experience more affordable so as to provide it to a greater proportion of students. ${ }^{76}$ These include developing student responsibility for clinic management and students being able to use their clinical experiences as an alternative form of assessment in other modules. Even then, the costs of running a law clinic and resourcing a CLE module can be substantial. There is therefore a need for a variety of other methods of teaching legal ethics in addition to the clinical approach.

Addressing the hidden curriculum through communities of practice is of particular relevance in the context of teaching legal ethics to law students from widening participation backgrounds. A community of practice is "a group of people who share a concern, a set of problems, or a passion about a topic and who deepen their knowledge and expertise in this area by interacting on an ongoing basis." 77 Communities of practice have three shared characteristics: a shared domain of interest, interactivity, and the development of a shared practice. ${ }^{78}$ Legal education is regarded as a specialised professional discourse of a community of practice. ${ }^{79}$ Ferguson proposes bringing disadvantaged students within the legal community of practice to become expert in ethical learning methods and assessment criteria and enhancing their social and cultural capital. ${ }^{80}$

Applying a community of practice approach to legal education would suggest that students are introduced to the idea that, from the time they enter law school, they are entering the legal professional community. In terms of practical teaching strategies, this could include: law schools working more closely with practising legal professionals, ${ }^{81}$ teaching students how to speak, write and read like lawyers ${ }^{82}$ and providing additional, targeted non-academic support for students from widening participation backgrounds. ${ }^{83}$ Key to the last of these strategies is making explicit to students the assumed understandings of the hidden curriculum as mentioned above. In the context of the LETR recommendations and the implementation of the SQE in particular Turner, Bone and Ashton consider that "enabling students to feel part of a community of practice will become increasingly important in a changing legal services market." 84 Employer feedback sought for revalidation purposes at UEL also recommends making "more explicit the opportunity to gain business and/or tech related knowledge and skills." 85 This suggests that such an approach would be supported by practising legal professionals.

However, becoming part of a community of practice will take time and require versatility and engagement on the part of students. The scale of this

\footnotetext{
${ }^{76}$ D. Nicolson, "Learning in justice: ethical education in an extra-curricular law clinic" in M. Robertson, L. Corbin, K. Tranter and F. Bartlett (eds), The Ethics Project in Legal Education (Abingdon, Routledge, 2011) pp. 171-190.

77 E. Wenger, R. McDermott and W.M. Snyder, Cultivating Communities of Practice: A Guide to Managing Knowledge (Harvard Business School Press, 2002) p.4.

78 Baron and Corbin, supra n.18.

${ }^{79} \mathrm{P}$. Moraitis and H. Murphy, "Language, Law and Identity: A Language and Learning Response to the Challenges of Widening Participation of Students in Law Subjects" (2013) 47(2) The Law Teacher 159-191.

80 Ferguson, supra n.36.

81 Baron and Corbin, supra n.18.

82 Moraitis and Murphy, supra n.79.

${ }^{83}$ Ferguson, supra n.36.

84 Turner, Bone and Ashton, supra n.23, p.15.

85 UEL, supra n.68, appendix 5.
} 
task should not be underestimated, as the LETR itself concludes that, "there is no single or predominant barrier to access [to the legal profession], and there are unlikely to be "quick fixes" to [such] a problem." ${ }^{6}$ This reflects the experience at UEL thus far, where attempts to implement some of the teaching and learning strategies referred to above in order to develop a community of practice have met with mixed success. For example, budgetary constraints limit the involvement of legal professionals in CLE and other modules and the provision of non-academic support such as student mentors, although levels of student engagement and satisfaction with such initiatives are consistently high as reflected in attendance and module evaluations. What is needed is a fully supported and structured approach for the programme to create a community of practice and a revalidation exercise provides an ideal opportunity to do this.

\section{Towards a legal ethics curriculum for widening participation students}

If broad curriculum-wide ethics learning outcomes are adopted for widening participation students in the terms referred to by Robertson, as stated above, there is a need for some understanding of what is meant by the term 'ethical competence'. The values that Chavkin ${ }^{87}$ believes can and should be taught focus on the lawyer's relationship with clients (includes how lawyers will demonstrate respect for and communicate effectively with clients); the lawyer's relationship to other lawyers and to judges (includes such values as civility to opposing counsel and candour to courts); and the lawyer's relationship with the profession (includes the obligation to provide pro bono representation and to strive consistently to improve the profession). For Nicolson ${ }^{88}$ those who teach ethics in law schools should have four goals: to inspire an interest in ethics in students, to illuminate the tools that ethics can provide for the resolution of ethical dilemmas, to illustrate the ethical dimension of legal practice by giving students experience in resolving dilemmas and to inculcate in students the habit of caring about, evaluating and identifying ethical issues. The outcomes of a professional ethics curriculum should, in the opinion of Boon, ${ }^{89}$ include: the underpinning of the ideological components of professionalism, the reinforcement of resistance to practice cultures, the inculcation of habits of ethical problem solving and the strengthening of professionalism.

Despite their differences of opinion, there is also considerable overlap in the views of Chavkin, Nicolson and Boon as to what the aims of a legal ethics curriculum should be and what ethical values should be taught to law students. This is reflected more widely in the literature on professional ethics, for example in the views of Cameron and O'Leary, ${ }^{90}$ who argue for evaluation

\footnotetext{
${ }^{86}$ Webb et al., supra n.2, para 109.

$87 \mathrm{D}$. Chavkin, "Experience is the only teacher: bringing practice to the teaching of ethics" in M. Robertson, L. Corbin, K. Tranter and F. Bartlett (eds), The Ethics Project in Legal Education (Abingdon, Routledge, 2011) pp. 52-78.

88 Nicolson, supra n.76.

89 A. Boon, "Ethics in Legal Education and Training: Four Reports, Three Jurisdictions and a Prospectus" (2014) 5(1) Legal Ethics 34-67.

${ }^{90}$ R. A. Cameron, and C. O'Leary, "Improving Ethical Attitudes or Simply Teaching Ethical Codes? The Reality of Accounting Ethics Education" (2015) 24(4) Accounting Education 275290.
} 
of moral as well as legal ethical dilemmas in accountancy education; van den Hoven and Kole, ${ }^{91}$ who assert that moral reflection is the aim of professional ethics education; and Tanchuk, Scramstad and Kruse, ${ }^{92}$ who make a case for a shared ethical professional understanding. The common thread in the literature seems to be that ethics is best understood when its principles are applied in a practical context and that the purpose of an ethics curriculum is to allow students to learn about and engage in ethical decision making in real life situations, challenging their own perspectives and understanding those of others while recognising that in reality there is usually more than one way to resolve a dilemma ethically, depending on the different factors and perspectives considered. In terms of ethical values, the students should think about honesty, impartiality, language, behaviour, confidence and support. Issues to examine in this context include whether lawyers should act for anyone irrespective of the morality of their client's objectives, how far lawyers should go in pursuing the interests of their clients, how to reconcile conflicts of interest and whether there should be limits to the lawyer's duty of confidentiality. Curriculum outcomes, and how to achieve them, can thus be identified.

Determining whether law students are able to exercise their own professional judgment involves ascertaining whether they are able to reflect on ethical principles and develop an ethical framework ${ }^{93}$ i.e. a context in which these standards and responsibilities apply. This will in the first place involve ensuring that instilled in students are some of the ethical behaviours mentioned in the preceding sections (e.g. handling cases with diligence, punctuality, courtesy and honesty) but it would also involve ensuring that students are engaging in critical evaluation of self and others (e.g. in class and in self-reflective journals) in order both to enhance their own understanding and develop the lifelong learning skills of the reflective practitioner. This can benefit widening participation students by facilitating awareness and management of their professional identity and future role as legal professionals in order to build their resilience.

Determining whether law students are able to recognise ethical challenges and dilemmas involves ascertaining whether students can, for example, see issues raised by representing both parties in a legal transaction $^{94}$ i.e. have they developed the ability to engage in ethical decisionmaking in practice? This will involve ensuring that habits of ethical problem solving have been inculcated in students so that they become a more or less instinctive response in practical contexts and also whether theory learned by students for the resolution of ethical dilemmas is actually being applied. For widening participation students this can assist in making explicit the assumed understandings and unarticulated value assumptions of the hidden curriculum.

Determining whether law students are able to consider legal issues from different ethical perspectives involves ascertaining whether students can,

\footnotetext{
${ }^{91} \mathrm{M}$. van den Hoven, and J. Kole, "Distance, dialogue and reflection: Interpersonal reflective equilibrium as method for professional ethics education" (2015) 44(2) Journal of Moral Education 145-164.

92 N. Tanchuk, C. Scramstad, and M. Kruse, "Toward an ethics of professional understanding" (2016) 11(1) Ethics and Education 5-16.

${ }_{93}$ Boon, supra n. 89 .

${ }^{94}$ Ferris, supra n.17.
} 
for example, identify and satisfactorily reconcile the perspectives of various stakeholders, including firms, clients and the general public ${ }^{95}$ i.e. have they developed an understanding of the purposes and limits of a lawyer's role? This will involve ensuring that students have a context for discussing the difference in values between different situations and considering how they will deal with role conflict e.g. being asked to represent unpopular clients or causes and handling relationships with opposing counsel, judges and other court and administrative agencies. In the context of widening participation, this can help illustrate to students the hallmarks of professionalism that they may be unaware of in the absence of suitable role models.

Overall, the above curriculum outcomes should prepare students for the SQE by aligning with the SRA's assessment objectives as referred to above. ${ }^{96}$ Hopefully they should also go beyond this in providing students with the skills, values and attitudes that any professional should possess (e.g. diligence, punctuality, courtesy, honesty and so on, as outlined above) by developing important competencies such as self-reflection, problem solving and professional judgment.

\section{Conclusion}

The focus of this paper has been how best to address the challenges of teaching legal ethics to law students from widening participation backgrounds. As such, detailed programme-wide ethics learning outcomes have been considered in fairly broad terms; in depth consideration of ethical curriculum design would almost certainly warrant a full study of its own. ${ }^{97}$ Based upon the preceding discussion and academic opinion, however, what can be said here is that it is at least desirable on completion of such a syllabus for widening participation students to be able to reflect on ethical principles and develop an ethical framework in order to exercise their own professional judgment, recognise ethical challenges and dilemmas, and consider legal issues from different ethical perspectives. Whatever shape it takes, the important thing for an ethics curriculum to do is to prepare law students to take the assessments necessary for entry to the legal profession (e.g. the SQE) and at the same time to provide them with the skills, values and attitudes that any professional should possess, as outlined above.

In terms of addressing the challenges of teaching legal ethics to widening participation students, a variety of approaches have been considered in this paper by reference to my own institutional context at UEL, each of which bring their own benefits and drawbacks. Neither the discrete nor pervasive approach used in isolation is likely to be sufficient; law schools ought to teach ethics both throughout the programme and in compulsory dedicated modules, with appropriate strategies for addressing the hidden curriculum and bringing widening participation students into the legal community of practice. The clinical approach appears to provide an effective vehicle for teaching ethics - research suggests that students with experience of law clinics and CLE modules have stronger moral identity, greater moral

\footnotetext{
${ }^{95}$ Evers and Townsley, supra n.15.

96 SRA, supra n. 13.

97 Robertson, supra n.66.
} 
attentiveness and lower senses of entitlement. ${ }^{98}$ Unfortunately, compared to other forms of teaching the clinical approach is also costly and resourceintensive. However, while it is possible for legal ethics to be marginalised by the adoption of discrete, pervasive or clinical approaches alone, there is no necessity to choose between these methods and no single best way of learning. ${ }^{99}$

The most effective way to teach ethics may be to use a combination of these approaches - indeed, in arguing for the clinical approach, Nicolson warns against abandoning all other means of equipping students for the moral challenges of legal practice. ${ }^{100}$ In revalidating the law degree at UEL this will be done by taking account of the sorts of approaches and strategies used to address the challenges of teaching legal ethics discussed above. For example, while legal ethics will continue to be taught and assessed at UEL as a discrete topic in the first year Legal System and Legal Reasoning module, the drawbacks of the discrete approach highlighted above will be tackled by taking a more structured and explicit approach to teaching ethics throughout the degree than was previously the case e.g. by adopting curriculum-wide ethics learning outcomes in the terms set out above. Similarly, given the benefits of the clinical approach in teaching legal ethics, the guidance referred to above provided by Curran et al. as to how CLE can be used to develop ethical understanding and by Nicolson as to how to make the clinical experience more widely available will also be incorporated in the newly validated law degree at UEL. As part of the revalidation, efforts will also be made to lobby for a budget to support a more structured approach for the programme to create a community of practice e.g. by providing additional, targeted non-academic support for students and working more closely with legal professionals. In light of the preceeding discussion this seems like a sound basis on which to proceed - and a timely one in view of the SQE's forthcoming implementation.

\footnotetext{
${ }^{98}$ R. Moorhead, C. Denvir, R. Cahill-O'Callaghan, M. Kouchaki and S. Galoob, "The ethical identity of law students" (2016) 23(3) International Journal of the Legal Profession 235-275. ${ }^{99}$ Chapman, supra n.59.

100 Nicolson, supra n.7.
} 